\title{
Factors Influencing Foreign Students' Satisfaction toward International Program in Thai Universities
}

\author{
Teerapat Ngamkamollert and Athapol Ruangkanjanases
}

\begin{abstract}
The objectives of this study were: 1) to explore factors that influence international students on their decision making process on selecting Thai universities as their preferred institution; 2) to identify the international students' satisfaction factors towards the international programs in Thai universities; $3)$ to identify and compare satisfaction factors between public and private universities; 4) to propose the improvement on increasing satisfaction of the international students who are studying in the international program at Thai universities, and to attract more potential international students in the future. This study is quantitative research using satisfaction questionnaire with five-point Likert scale as a tool to measure the satisfaction level and primary data was collected from 271 foreign students studying in international programs in Thai universities.

Eight key factors were incorporated and formulated in a conceptual model tested in this study. Data analysis and hypothesis testing were performed by using Pearson's product moment correlation, stepwise multiple regression, and cross tabulation. The findings indicated that only four factors had significant positive influence on overall foreign students' satisfaction toward international program in Thai higher education. These four factors were academic and education quality, financial and economic consideration, administrative and staff support, and image and prestige of the university. The multiple regression model with these four factors could predict $51.3 \%$ of the variance in the overall student satisfaction and the respondents' results' regarding overall satisfaction rating was in satisfied level.
\end{abstract}

Index Terms-Foreign, students, factors, influencing, satisfaction, international, program, Thai universities.

\section{INTRODUCTION}

With the current fast pace of economic growth, the education sector is considered to be a key integral part for the better overall economics' driving forces and major parts for the country development. Moreover, with globalization, the higher education sector is being internationalized by the mobility of institutions and students. Most of the international students are pursuing a better education programs that are being offered elsewhere other than their host countries in order to pursue a better opportunities in the future.

In 2010, the international student population has reached nearly 3.6 million worldwide. It rises almost $50 \%$ over the past six years [1]. There was an increase of $4.7 \%$, from 690,923 to 723,277 , in mobility of international students in

Manuscript received January 25, 2014; revised March 28, 2014.

Teerapat Ngamkamollert and Athapol Ruangkanjanases are with Chulalongkorn Business School, Chulalongkorn University, Thailand (e-mail: teerapat.ng558@cbs.chula.ac.th, athapol@cbs.chula.ac.th). the academic year of 2010-2011 [2].

According to the survey conducted by Office of the Higher Education Commission [3] in 2012, there were 20,309 foreign students, from 130 countries, enrolled in 103 Thai higher education institutions in 2011. The number of foreign students had increased by $0.74 \%$ from the 2010 . The top three sending countries are China $(8,444)$, Myanmar $(1,481)$, and Laos $(1,344)$ respectively. Region-wise, the largest body of international students was from Asia $(17,287)$. The total numbers of foreign students were increased annually in the previous five years from 11,021 students in 2007 to 20,309 students in 2011.

Higher education industry is growing strong and has high competition level. In order to attract more prospect foreign students to select Thailand as their preferred educational destination, satisfying the current students will be the best and most effective way to promote Thai education because word-of-mouth is an important role to make it successful. Therefore, it is critical to identify factors that influence foreign students' satisfaction toward international program in Thai higher education institutions.

\section{LITERATURE REVIEW}

\section{A. Herzberg's Two-Factor Theory}

Frederick Herzberg's motivation-hygiene factor theory has become one of the most well recognized and extensively used theories for deriving the motivation and satisfaction factors.

The first set of factors was "motivators" or "satisfiers", which usually involves "job content" (motivation factors) and tend to lead to job satisfaction. The other set of factors was "hygiene factors" or "dissatisfies", which usually involves "job context" (hygiene factors) and will be resulted in dissatisfaction when things are being deficient.

According to DeShields Jr., Kara and Kaynak [4], the faculty performance and classes were considered to be satisfiers. These two influences are directly related to students' college experience and satisfaction. On the contrary, the performance of advising staff is considered to be hygiene factor which could cause dissatisfaction.

\section{B. Social Learning Theory}

Wang, Taplin and Brown [5] used McLeod and Wainwright's social learning theory to assess mainland Chinese students' satisfaction of the study abroad program. Their study examined factors based on an individual's internal factor ("preparation") and external factors faced in a study abroad program ("culture" and "technical teaching") which are beyond an individual's control. Their findings 
suggested that Chinese students' preparation before studying abroad was essential for the students to do well in the program. In addition, the students who felt they were better prepared for study abroad showed higher satisfaction.

\section{Structural Equation Model of Student Satisfaction}

Arambewela and Hall [6] developed a model of student satisfaction. They used structural and equation model to analyze their data because it could deliberate the overall test of model fit. It could also represent causal approach in examining set of relationships between independent variables and independent variables. The results indicated that these seven factors: education, social, technology, economic, accommodation, safety, and prestige and image are significant predictors of student satisfaction.

\section{Student Satisfaction and Retention Model (SSRM)}

Referring to DeShields Jr., Kara and Kaynak [4], the modified version of Student Satisfaction and Retention Model was used in order to measure the satisfaction level of the student. Three most important variables: faculty performance, advising staff performance, and classes, which believed to be critical in influencing student's experience in university and have impact on overall student satisfaction, were tested.

These three core factors were used in this model in order to determine the overall student satisfaction. Results found from this study showed that faculty performance (lecturer) and classes were significant factors that influence on their university experiences. Furthermore, the students with positive college experience were more satisfied with their university than those who were not.

\section{E. HEdPERF (Higher Education PERFormance-only)}

According to Firdaus [7], HEdPERF was relatively new and more inclusive performance-based used for measuring scale of the determinants of service quality within higher education sector. Six core dimensions were identified as: non-academic aspects, academic aspects, reputation, access, programme issues, and understanding, to be distinctly related to the student perceptions of service quality.

By knowing strong and weak points of these dimensions and their relative influence, the result would help for better provision of resources and to deliver a better service to students. From the analysis, the result showed that only one dimension was significant toward the overall student rating, which was "access". The students perceived access (approachability, ease of contact, availability and convenience) to be more important than others factors.

\section{F. Past Researches Information Focusing on Similar Aspects}

Researches related to this study were also reviewed for the conceptual model. Gamage, Suwanabroma, Ueyama, Hada, and Sekikawa [8] from University of Newcastle, Australia, explored students' perception on quality of services provided by private universities in Thailand and Japan, and how these perceptions affect their decision in selecting a university. It was a comparative study aiming at focusing on how cultural and financial factors would affect their decision. Total of eleven factors were used for this study: Quality of academic staff, Quality of academic programs, University's reputation, financial assistance and tuition fees, Counseling and support services, Job placement services, Grievance procedures, Physical plant facility, Library and computer facilities, and Student organizations and recreational facilities. These 11 factors were categorized into three service types; Academic aspect, Non-academic aspect, and Facilities aspect. Total of 1,900 Thai students from nine private universities and 703 Japanese students from two private colleges participated in this survey. The results showed that the most important factors that influence students to select the university are the university's reputation, academic staff, quality of the programs and job-placement. The results also showed that there were similarities for both cultures, but Thai had higher degree of satisfaction than the Japanese.

Qi Huang [9] studied the relation between service quality and satisfaction, and further investigated the relation between non-academic aspects, academic aspects, teaching methods, program issues, reputation, and access, cost and student satisfaction of undergraduate students in Xiamen University of China. From 397 respondents, the questionnaire was designed using seven-points Likert-scale. The results showed that the most significant factor was the relation between service quality and students' satisfaction in terms of academic aspects of undergraduate in Xiamen University of China, followed by the relation in terms of non-academic aspects, terms of cost, terms of access, terms of teaching methods, and terms of industry links.

According to Techachaicherdchoo [10]'s study, "Undergraduate Student's Satisfaction toward the New Education System in Thailand", the study was focus on the students' perception toward the quality of Thai university. The developed model for measuring satisfaction consist of the following factors; knowledge of teacher, skill of teacher, curriculum, tuition fee, and word of mouth's effect. The sample surveys were distributed to 400 undergraduate students, but there were only 374 samples that are usable for analyze. The results concluded that the student satisfaction increased along with the knowledge of the teacher and curriculum quality. The word of mouth also could lead to increase satisfaction.

From Suh Li Phang [11]'s study, the researcher intended to investigate the factors that influence the international students' decision to select their study destination. This study had selected qualitative interviews for measuring the satisfaction. The study comprised of eight interviews with current international students and graduated international master students. The results indicated three categories of influenced factors; communication, location, and social. The communication factors consisted of the quality of the communication through online and offline channels. The location factors consisted of the attractiveness of the study destination, an institutional image, desired program or course, language, international environment, and costs. Lastly, the social factors consist of the social network which included family and friends, former professors, and student testimonials.

Asaduzzaman, Hossain, and Rahman [12] attempted to 
examine the relationship between service quality dimensions and overall service quality which included tangibility, responsiveness, reliability, assurance, and empathy, and the student satisfaction. To obtain the data, 550 questionnaires were distributed to the business major's students from Private Universities. The most significant factors included the tangibles facilities and atmosphere such as cleanliness, appearance, and classroom. As for the reliability factors, the significant factors were providing service in time, teaching capabilities of teachers, and services and capabilities of staffs.

According to the study of Mehdipour and Zerehkafi [13], the development of student satisfaction will be the primary focus for higher education institution because it will help the university facilitate the strategic and objectives more effectively. Various factors were adopted from the quality of academic courses/programs, the services of staffs, and the overall facilities' quality and images. The questionnaires were distributed to 900 university students. The results showed that the reasons for the students to select the institution were; the right program or course available, the availability of computers, quality of library facilities, teaching reputation, availability of areas for self-study, quality of public transport, and friendly attitude toward students.

\section{RESEARCH Methodology}

\section{A. Conceptual Framework}

The conceptual framework of this study was constructed from the literature review and previous studies stated. However, the factors were adapted to suit to the environment of the study. The researchers formulated a conceptual model which consists of one internal factor and seven external factors, as independent variables, which were assumed to have an impact on student satisfaction. Overall foreign students' satisfaction was used as a dependent variable. The conceptual model is shown in Fig. 1.

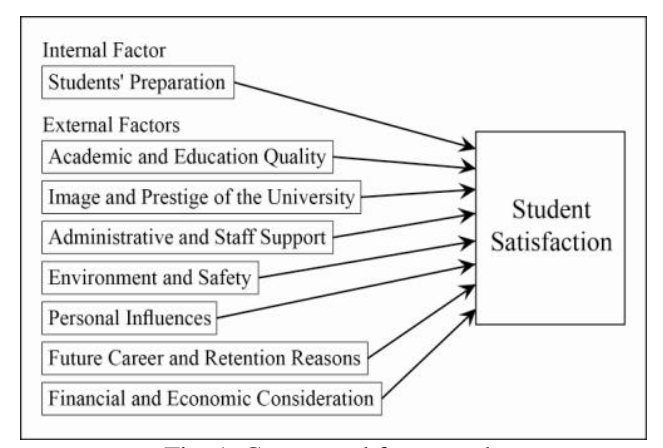

Fig. 1. Conceptual framework.

Based on the conceptual framework, hypotheses of this study were as follows:

H1: All eight factors (student's preparation, student satisfaction with; academic and education quality, image and prestige of the university, administrative and staff support, environment and safety, financial and economic consideration, future career and retention reasons, and personal influences) will have a positive relationship with overall student satisfaction.
H2: All eight factors (student's preparation, student satisfaction with; academic and education quality, image and prestige of the university, administrative and staff support, environment and safety, financial and economic consideration, future career and retention reasons, and personal influences) will be the significant predictors of overall student satisfaction.

\section{B. Data Collection}

Questionnaire was formulated from the literature review and previous studies, and designed to attain the objectives of the study. It consists of four parts: 1) respondents' personal information; 2) overall satisfaction of international students from international program in Thai Universities as their educational destination; 3) foreign students' satisfaction toward all eight factors; and 4) comments and suggestions.

A set of 30 questionnaires were first handed out to international students for reliability test. The data were collected and analyzed the reliability by using Cronbach's Alpha. The score was 0.966, using the rule of George and Mallery [14]; the score was interpreted as excellent because the closer the coefficient is to 1.0, the greater is the internal consistency of the items (variables) in the scale.

Using 95 percent confidence level with sampling error of 5 percent based on Yamane [15], sample size was 392. Questionnaires were distributed to foreign students who were studying in both public and private Thai higher education institutions and a total of 271 completed questionnaires were acquired.

\section{Measures}

This study applied a five-point Likert scale, ranging from Very Unsatisfied 1) to Very Satisfied 5), to measure foreign students' satisfaction with eight dimensions. The measurement of student satisfaction was completed through a multi-structure. First, respondents had to rate the levels of their overall satisfaction from selecting Thai Universities as their educational destination, followed by rating the levels of their satisfaction with international program in Thai Universities with each dimension. This method could generate reflection on each factor which considered being significant to the overall student satisfaction.

\section{Independent Variables}

The independent variables consisted of one internal factor; students' preparation and seven external factors; academic and education quality, image and prestige of the university, administrative and staff support, environment and safety, financial and economic consideration, future career and retention reasons, and personal influences. These factors were hypothesized to have an impact on dependent variable.

Regarding to students' preparation, the questionnaire had 4 items under this factor. This matter measured how well foreign students prepared themselves before coming to study in Thailand; preparation for English, studying, living in Thailand, and research on potential Thai university. Academic and education quality was a straight forward academic issue; the questionnaire had 7 items used to measure students' satisfaction toward: education contents, standard, quality of faculty and staffs, skills, attitude, and assignments. Image and prestige of the university was related 
to the reputation of the university. The questionnaire had 3 items used to measure students' satisfaction toward: reputation of academic program and department nationally and internationally, and the strength of the alumni network. Four items were asked for the administrative and staff support, the issues related to the application and registration processes, counseling services, and willingness of support. Environment and safety consisted of 4 items, which related to safety around campus, the recreation facilities, issues concerning racial and reputation for safety. For financial and economic consideration, it consisted of 4 items: cost of the programs, living expenses, payment plans, and scholarship. Future career and retention reason had 4 items, which related to career development, training, skills gained, attaining job, and working permit. Finally, personal influence had 4 items: advises from parents/guardians, friends, job prospect and friends who still studying in Thailand.

TABLE I: FREQUENCY (NUMBERS) AND PERCENTAGE OF RESPONDENTS

\begin{tabular}{lcc}
\multicolumn{3}{c}{ ClASSIFIED BY PERSONAL FACTORS $(N=271)$} \\
\hline \hline Personal Factor & $\begin{array}{c}\text { Frequency } \\
(\mathbf{n})\end{array}$ & $\begin{array}{c}\text { Percentage } \\
(\boldsymbol{\%})\end{array}$ \\
\hline Gender & 90 & 33.2 \\
Male & 181 & 66.8 \\
Female & & \\
\hline
\end{tabular}

\begin{tabular}{lcc}
\hline Age $($ Mean = 23.0277)** & & \\
$15-19$ & 43 & 15.9 \\
$20-24$ & 178 & 65.7 \\
$25-29$ & 41 & 15.1 \\
30 and over & 9 & 3.3 \\
\hline
\end{tabular}

\begin{tabular}{|c|c|c|}
\hline $\begin{array}{l}\text { Country } \\
\text { Cambodia }\end{array}$ & 2 & 0.7 \\
\hline China & 152 & 56.1 \\
\hline India & 3 & 1.1 \\
\hline Japan & 15 & 5.5 \\
\hline Korea & 10 & 3.7 \\
\hline Laos & 3 & 1.1 \\
\hline Myanmar & 23 & 8.5 \\
\hline USA & 24 & 8.9 \\
\hline Vietnam & 2 & 0.7 \\
\hline Bhutan & 1 & 0.4 \\
\hline Belgium & 2 & 0.7 \\
\hline France & 1 & 0.4 \\
\hline Germany & 6 & 2.2 \\
\hline Sweden & 1 & 0.4 \\
\hline Austria & 1 & 0.4 \\
\hline Netherlands & 1 & 0.4 \\
\hline Finland & 2 & 0.7 \\
\hline Italy & 2 & 0.7 \\
\hline Mexico & 3 & 1.1 \\
\hline Australia & 4 & 1.5 \\
\hline Russia & 5 & 1.8 \\
\hline Poland & 1 & 0.4 \\
\hline Canada & 1 & 0.4 \\
\hline Switzerland & 3 & 1.1 \\
\hline Taiwan & 1 & 0.4 \\
\hline Jordan & 1 & 0.4 \\
\hline United Kingdom & 1 & 0.4 \\
\hline
\end{tabular}

University Type

\begin{tabular}{|c|c|c|}
\hline Public University & 112 & 41.3 \\
\hline Private University & 159 & 58.7 \\
\hline \multicolumn{3}{|l|}{ University Name } \\
\hline Burapha University & 3 & 1.1 \\
\hline Chulalongkorn University & 15 & 5.5 \\
\hline Korn Kaen University & 1 & 0.4 \\
\hline Mahidol University & 2 & 0.7 \\
\hline Thammasat University & 59 & 21.8 \\
\hline Assumption University & 2 & 0.7 \\
\hline Bangkok University & 17 & 6.3 \\
\hline Dhurakij Pundit University & 74 & 27.3 \\
\hline Rangsit University & 64 & 23.6 \\
\hline Siam University & 2 & 0.7 \\
\hline $\begin{array}{l}\text { King Mongkut's Institute of } \\
\text { Technology North Bangkok }\end{array}$ & 1 & 0.4 \\
\hline Mae Fah Luang University & 13 & 4.8 \\
\hline Chiang Mai University & 3 & 1.1 \\
\hline Phetchaburi Rajabhat University & 3 & 1.1 \\
\hline Kanchanaburi Rajabhat University & 8 & 3.0 \\
\hline Nakhon Sawan Rajabhat University & 1 & 0.4 \\
\hline $\begin{array}{l}\text { The University of Thai Chamber of } \\
\text { Commerce }\end{array}$ & 3 & 1.1 \\
\hline \multicolumn{3}{|l|}{ Field of study } \\
\hline Business English & 7 & 2.6 \\
\hline Communication Arts & 16 & 5.9 \\
\hline English Language & 3 & 1.1 \\
\hline $\begin{array}{l}\text { Hospitality and Tourism } \\
\text { Management }\end{array}$ & 7 & 2.6 \\
\hline International Business & 47 & 17.3 \\
\hline Management & 6 & 2.2 \\
\hline Marketing & 7 & 2.6 \\
\hline Thai for Communication & 11 & 4.1 \\
\hline Thai Language & 53 & 19.6 \\
\hline Engineering & 3 & 1.1 \\
\hline $\begin{array}{l}\text { International Communication } \\
\text { Technology }\end{array}$ & 8 & 3.0 \\
\hline $\begin{array}{l}\text { Management Information } \\
\text { Technology }\end{array}$ & 2 & 0.7 \\
\hline Multimedia & 1 & 0.4 \\
\hline Thai Studies & 18 & 6.6 \\
\hline Human Resource Management & 3 & 1.1 \\
\hline Philosophy, Politics and Economics & 1 & 0.4 \\
\hline Inter Relation \& Development & 1 & 0.4 \\
\hline Bio-Technology & 1 & 0.4 \\
\hline Accounting and Finance & 1 & 0.4 \\
\hline Public Health & 1 & 0.4 \\
\hline Entrepreneurship & 1 & 0.4 \\
\hline Political Science & 2 & 0.7 \\
\hline Sociology & 1 & 0.4 \\
\hline Journalism & 1 & 0.4 \\
\hline Law & 1 & 0.4 \\
\hline $\begin{array}{l}\text { Level of study } \\
\text { Bachelor's degree }\end{array}$ & 212 & 78.2 \\
\hline Master's degree & 39 & 14.4 \\
\hline Doctoral degree & 3 & 1.1 \\
\hline Certificate & 17 & 6.3 \\
\hline
\end{tabular}

\section{E. Dependent Variable}

Overall student satisfaction was the only dependent 
variable in this study. It was assumed to be under influenced by all eight independent variables. Five items were asked as follows; I think I have made the right decision to study in Thailand, I think I have made the right decision to study international program in Thailand, The expense of coming to study in Thailand was well worth it, I will continue to keep in touch with my university after my studies, and I will recommend Thailand as a study destination to my friends.

\section{DATA ANALYSIS}

Descriptive statistics was used to gain personal characteristics of the respondents, their level of satisfaction and preparation. For the hypotheses testing, Pearson's correlation, and stepwise multiple regression analysis were performed in order to identify the relationships between all eight factors (independent variables), and overall student satisfaction (dependent variable), and to examine which factors have the predictive power on the overall student satisfaction. In order to fulfill the objective, cross tabulation analysis was used to perform the comparison satisfaction level between Public and Private Universities.

From the sample of 271 foreign students who are studying in international program in Thai higher education institutions, the research findings were concluded and categorized into 4 parts as follows;

\section{Part 1: Demographic Data of the Respondents}

The majority of respondents were female. Students in the age range of 20-24 were the largest group. Most of the respondents were from China. Most respondents enrolled in Private Universities. The largest group of students selected Business administration as their field of study. Lastly, the majority of respondents were in undergraduate level. Further details are shown in Table I.

\section{Part 2: Summary of Descriptive Statistics of All Variables}

From the results, the level of student's overall preparation was in good level (Mean $=3.51, S D=0.829)$. Regarding the foreign students' satisfaction toward variables related to the higher education, the results showed that the overall satisfaction level of the respondents toward international program in Thai universities was in satisfied level (Mean = 3.72, $S D=0.880$ ). Looking further in details toward each aspect, the highest satisfied factor was environment and safety with satisfied level (Mean $=3.85, S D=0.807)$. The second highest satisfied factor was administrative and staff support with satisfied level $($ Mean $=3.75, S D=0.821)$ as well. The least satisfied factor was image and prestige of the university (Mean $=3.43, S D=0.896$ ), but it was still in satisfied level. More details are shown in Table II.

TABLE II: SUMMARY OF DESCRIPTIVE STATISTICS $(N=271)$

\begin{tabular}{lccc}
\hline \multicolumn{1}{c}{ Variables } & Mean & $\begin{array}{c}\text { Std. } \\
\text { Deviation }\end{array}$ & Meaning \\
\hline $\begin{array}{l}\text { Internal Factor } \\
\text { Preparation }\end{array}$ & 3.51 & .829 & Good \\
\hline External Factor & & & \\
Academic \& Education Quality & 3.62 & .773 & Satisfied \\
$\begin{array}{l}\text { Image \& Prestige of the } \\
\text { University }\end{array}$ & 3.43 & .896 & Satisfied \\
Administrative \& Staff Support & 3.75 & .821 & Satisfied \\
$\begin{array}{l}\text { Environment \& Safety } \\
\text { Financial \& Economic }\end{array}$ & 3.85 & .807 & Satisfied \\
Consideration & 3.55 & .826 & Satisfied \\
$\begin{array}{l}\text { Future Career \& Retention } \\
\text { Reasons }\end{array}$ & 3.49 & .852 & Satisfied \\
Personal Influences & 3.44 & .815 & Satisfied \\
\hline Overall Satisfaction & $\mathbf{3 . 7 2}$ & $\mathbf{. 8 8 0}$ & Satisfied \\
\hline \hline
\end{tabular}

Part 3: Analysis of Factors Influencing Foreign Students' Satisfaction (Hypothesis Testing)

For Hypothesis 1 (H1)'s testing, Pearson's product correlation was performed in order to identify the relationships between eight independent variables. Furthermore, for Hypothesis 2 (H2)'s testing, multiple regression was applied in order to examine the predictive power of all eight factors on the overall student satisfaction. The two hypotheses were tested and concluded as follows;

1) Correlation analysis

TABLE III: SUMMARY OF CORRELATION AMONG EIGHT VARIABLES $(N=271)$

\begin{tabular}{|c|c|c|c|c|c|c|c|c|c|}
\hline Variables & 1 & 2 & 3 & 4 & 5 & 6 & 7 & 8 & 9 \\
\hline 1. Self-preparation & & $.564^{* *}$ & $.565^{* *}$ & $.508^{* *}$ & $.487^{*}$ & $.598^{* *}$ & $.572^{* *}$ & $.493^{* *}$ & $.530^{* *}$ \\
\hline 2. Academic \& Education Quality & & & $.773^{* *}$ & $.544^{* *}$ & $.666^{*}$ & $.646^{* *}$ & $.777^{* *}$ & $.615^{* *}$ & $.669^{* *}$ \\
\hline 3. Image \& Prestige of the university & & & & $.509^{* *}$ & $.571^{*}$ & $.598^{* *}$ & $.704^{* *}$ & $.563^{* *}$ & $.613^{* *}$ \\
\hline 4. Administrative \& Staff support & & & & & $.588^{*}$ & $.544^{* *}$ & $.533^{* *}$ & $.481^{* *}$ & $.523^{* *}$ \\
\hline 5. Environment \& Safety & & & & & & $.618^{* *}$ & $.654^{* *}$ & $.558^{* *}$ & $.557^{* *}$ \\
\hline 6. Financial \& Economic Consideration & & & & & & & $.739^{* *}$ & $.564^{* *}$ & $.597^{* *}$ \\
\hline 7. Future Career \& Retention Reasons & & & & & & & & $.659^{* *}$ & $.617^{* *}$ \\
\hline 8. Personal Influences & & & & & & & & & $.526^{* *}$ \\
\hline 9. Overall Satisfaction & & & & & & & & & \\
\hline
\end{tabular}

H1: All eight factors (students' preparation, student satisfaction with; academic and education quality, image and 
prestige of the university, administrative and staff support, environment and safety, financial and economic consideration, future career and retention reasons, and personal influences) will have a positive relationship with overall student satisfaction.

Table III disclosed that the all eight independent variables had significant positive relationship with the dependent variable (overall student satisfaction), ranged from $r=0.523$ to $r=0.669$ and were significant at 0.000 level. In details, the factor that has the highest positive relationship with overall student satisfaction was students' satisfaction with academic and education quality $(r=0.669, p=0.000)$, followed by future career and retention reasons $(r=0.617, p=0.000)$, image and prestige of the university $(r=0.613, p=0.000)$, financial and economic consideration $(r=0.597, p=0.000)$, environment and safety $(r=0.557, p=0.000)$, students' self-preparation $(r=0.530, p=0.000)$, personal influences $(r$ $=0.526, p=0.000)$, and the lowest positive relationship was administrative and staff support $(r=0.523, p=0.000)$ Hence, the Hypothesis 1 was asserted.

\section{2) Step-wise multiple regression analysis}

H2: All eight factors (students' preparation, student satisfaction with; academic and education quality, image and prestige of the university, administrative and staff support, environment and safety, financial and economic consideration, future career and retention reasons, and personal influences) will be the significant predictors of overall student satisfaction.

TABLE IV: SUMMARY RESUlT OF STEPWISE MULTIPLE REGRESSION ANALYSIS AMONG VARIABLES $(N=271)$

\begin{tabular}{|c|c|c|c|c|c|c|c|c|}
\hline \multicolumn{2}{|r|}{ Criterion: Overall satisfaction } & & & & .722 & .521 & .513 & $72.224 * * *$ \\
\hline \multirow[t]{3}{*}{ Predictor: } & 1. Academic \& Education Quality & .380 & .334 & $4.586^{* * *}$ & & & & \\
\hline & $\begin{array}{l}\text { 2. Financial \& Economic } \\
\text { Consideration }\end{array}$ & .221 & .207 & $3.510 * * *$ & & & & \\
\hline & 4. Image \& Prestige of the university & .152 & .155 & $2.254 * *$ & & & & \\
\hline
\end{tabular}

Note: Significance level: $* * p<0.05, * * * p<0.01$

In Table IV, the overall student satisfaction was defined as criterion or dependent variable. After stepwise multiple regressions was applied, the result shown that with all eight variables, only four independent variables were shown to be the significant predictors of the overall student satisfaction. These four factors were: satisfaction with: academic and education quality, financial and economic consideration, administrative and staff support, and image and prestige of the university.

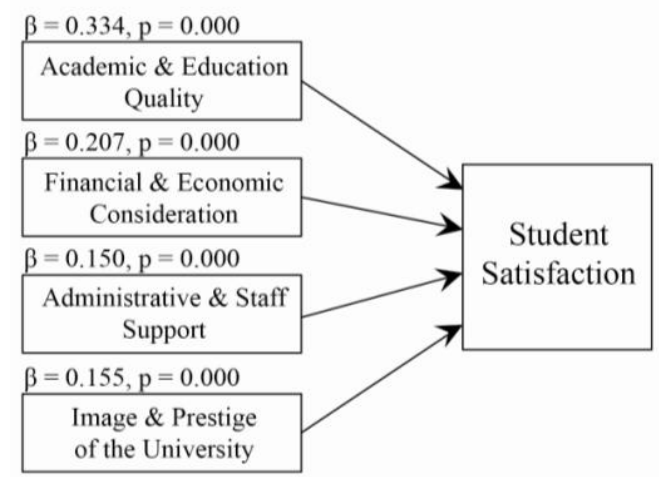

Fig. 2. Multiple regressions model.

Hypothesis 2 was partially confirmed because only four factors were shown to be significantly influenced on the overall student satisfaction. The multiple regression model for these four variables also shown that these factors could accounted for $51.3 \%$ of the variance in the overall student satisfaction (Adjusted $R^{2}=0.513$ ).

From the four factors, satisfaction with academic and education quality has the largest Beta coefficient $(\beta=0.334$, $p=0.000)$, followed by financial and economic consideration $(\beta=0.207, p=0.000)$, administrative and staff support $(\beta=0.150, p=0.000)$, and image and prestige of the university ( $\beta=0.155, p=0.000)$, and keeping all other variables constant.

In conclusion, academic and education quality was shown to have the highest significant predictive power and positive influence on overall students' satisfaction toward international program in Thai Universities, followed by financial and economic consideration, administrative and staff support, and image and prestige of the university, respectively. The multiple regression model was illustrated in Fig. 2.

\section{Part 4: Cross Tabulation Analysis between Public and Private Universities}

In order to fulfill the third objective, the cross tabulation analysis was performed to show results by university type. The mean score was used to compare and sorted out the most and least satisfaction level of the respondents. The results were showed in Table V.

For both public and private university's international students, every respondent's highest satisfaction is the environment and safety. The mean score of public university was 3.91 while the mean of private university was 3.80 . The second highest satisfaction for both public and private universities' respondents was toward administrative and staff support (Mean = 3.82 and 3.70). For the third highest satisfaction rank of both type of university was toward academic and education quality (Public university's mean = 3.70, Private university's mean $=3.56$ ).

As for the lowest mean scores, these showed the least satisfaction levels of the international students. The lowest mean score of public universities was for personal influence factor (Mean $=3.47$ ) while the lowest mean score of private universities was for image \& prestige of the university (Mean $=3.31$ ). 
TABLE V: MEAN SCORE OF ALL FACTORS BETWEen PUBLIC AND PRIVATE UNIVERSITIES

\begin{tabular}{lcc}
\hline \hline & \multicolumn{2}{c}{ UNIVERSITY TYPE } \\
\cline { 2 - 3 } & Public University & $\begin{array}{c}\text { Private } \\
\text { University }\end{array}$ \\
\cline { 2 - 3 } & Mean & Mean \\
\hline $\begin{array}{l}\text { Internal Factor } \\
\text { Self-preparation }\end{array}$ & 3.62 & 3.43 \\
$\begin{array}{l}\text { External Factors } \\
\text { Quademic \& Education }\end{array}$ & 3.70 & 3.56 \\
$\begin{array}{l}\text { Image \& Prestige of the } \\
\text { university }\end{array}$ & 3.61 & 3.31 \\
$\begin{array}{l}\text { Administrative \& Staff } \\
\text { support }\end{array}$ & 3.82 & 3.70 \\
$\begin{array}{l}\text { Environment \& safety } \\
\text { Financial \& Economic } \\
\text { Consideration }\end{array}$ & 3.91 & 3.80 \\
$\begin{array}{l}\text { Future Career \& } \\
\text { Retention Reasons } \\
\text { Personal Influences }\end{array}$ & 3.66 & 3.48 \\
\hline Overall Satisfaction & 3.50 & 3.48 \\
\hline \hline
\end{tabular}

\section{CONCLUSION AND DISCUSSION}

From the findings, the results disclosed that only four factors; Academic \& Education Quality, Financial \& Economic Consideration, Administrative \& Staff Support, and Image \& Prestige of the university, have significant positive influence on overall international students' satisfaction toward international program in Thai universities.

Firstly, for academic \& education quality, this factor is directly related to the education and mainly determined by the factors related to the quality of academic staff and programs. Several studies showed support for this factor, the finding of [4] confirmed that students who had a positive experience were more likely to be satisfied with the university. The positive students' satisfaction came from the positive college experience, in this case, the services provided by the program and university, which were the education quality i.e. real world relevance and the teaching quality and skills of the lecturers.

Furthermore, results from [8] indicated that the quality of the programs was one of the most important factors that affected students' satisfaction. The subject contents of the curriculum need to focus on preparing for the workplaces because the students rated "Knowledge and skills gained in my courses will provide good jobs" as the most satisfactory aspect. They believed that the purpose of higher education is to prepare for employment and developing skills to achieve that goal.

Moreover, the finding of [6] confirmed that the majority of surveyed believed that the feedback from lecturers, good access to lecturers, and quality of teaching were perceived to be the most important factors influencing students' satisfaction. The study also highlighted the importance of teaching quality and the role of teaching staff in order to generate student satisfaction. In addition, the academic programs in terms of content and quality were also important factor that influenced satisfaction. The Education factor is the most significant toward the students' satisfaction. Within the Education construct, the important of feedback from the lecturers, good access to lecturers, and quality of teaching are perceived to be the most important variables that influencing student satisfaction.

According to the finding of [9], the academic aspects had very strong positive relationship with student satisfaction in teaching methods, program issues, and quality of curriculum. The results confirmed the important of these variables because student satisfaction would improve with the improving effort in program issues. The students from Xiamen University agreed that the quality, the range of selection, or the structure of the program were not good enough.

Regarding the second factor, Financial \& Economic Consideration, it was related to the financial assistance and the tuition cost of the academic program. It can be determined by looking at the financial assistance given to the students; the expenses needed during the time of study, the tuition fee payment plan, the scholarship offered, extra income from part-time job, and so on. The finding of [8] indicated that the financial assistance and tuition fees were the second most important factor that influenced the students' satisfaction.

The result of [6] supported that within the economic consideration factor, the migration opportunities, part time jobs, and cost of living are considered as the most important variables. For example, in their case, Australia allowed international students to work. However, securing part time job was not easy for most students' especially newly-arrived students. Since, most of students expect to find a part-time job in their area of interest. The negative experience would result in the overall satisfaction.

In the study of [11], the researcher indicated that most of respondents were not affected by the tuition fee factor in Swedish Higher Education. However, the major reason was because the free tuition fee was given to the student by the government. Therefore, it is confirmed that the influences of respondents' satisfaction was dictated by the free tuition fee. Moreover, the lower living expenses were also a factor that influences their satisfactory level.

Regarding the third factor, Administrative \& Staff Support was another significant factor that could influence foreign students' satisfaction. Within this aspect, the administrative and staff support related directly to the quality of services offered by the staffs; eagerness to provide information, good manners, understanding the problems at hand, problem solving abilities, and effectiveness.

In [6]'s study, researchers confirmed that international students considered the counseling services and orientation programs as most important variables. For example, many international students went through stress and adjustment difficulties during the initial period of their first enrollment at the university. The student counseling services played an important role to support the newly enrolled students. Plus, the student orientation program also played an important part in the support services because the students considered such program have tremendous value to them.

Another study supported that effective institution counseling support service was bound to be one important factor in helping student academic success [8]. This study also demonstrated that this is the third most important factor that influences student satisfaction. The finding implied that students value the availability of counseling support services 
to help them with academic as well as personal problems.

Finally the stepwise multiple regression analysis's result confirmed that Image \& Prestige of the University is another significant factor that influences student satisfaction. This aspect is believed to create better career opportunities for the students. The finding of [6] indicated that gaining international image and prestige as an educational institution require commitment to excellence in the delivery of education. For example, most international students believe that some Australian universities enjoy high image and prestige among Asian countries. Therefore, the reputation and recognition of an institution is loosely based on the strength and capacity of the university to deliver and fulfill the expectation of students.

Moreover, the study indicated that the institution's academic courses, lecturers, and comparative ranking with overall universities are concerned by the students. The high image and prestige of the institution could create better opportunities in the job market. Hence, the attractiveness of the universities relies on its reputation, image and quality locally, internationally, and in home country of the students.

\section{RECOMMENDATION}

In accordance with the findings, several needed improvements can be identified. There were four factors, academic and education quality, financial and economic consideration, administrative and staff support, and image and prestige of the university, which had significant positive influence on overall international students' satisfaction toward international program in Thai universities. Although these factors were not in unsatisfied level, but Thai higher education institutions should attempt to improve it in order to gain more student satisfaction because the most compelling and persuasive way to attract prospective international students is "word of mouth" referrals. Therefore, the following suggestions were provided for the Thai higher education institutions.

Thai government should assist higher education institutions in developing their academic and professional capacities to meet international standards. Quality assurance should be promoted for both public and private universities. To gain more international recognition, the Ministry of Education needs to make great efforts on putting more advertisements and promotions for Thai higher education to increase more international awareness and promote Thai higher education. Participating or organizing international education exhibitions or road shows should be encouraged.

Based on the findings, the lowest mean score for public universities was from personal influence factor. Even though the finding indicated that it was not significantly influencing factor, however, by improving the satisfaction level of this factor would still make the overall mean score higher. Since most of the attributes were related to advices of families and friends, current students' experiences would be the key because they would be channels to share and give advices to both current and prospective students about their educational experiences.

The lowest mean score for private universities was from the image and prestige of the university. This was critical because this factor was one of the 4 influencing factors.
Trying to improve university ranking could be a key. According to Hess and Hochleitner [16], high rankings boost an institution's prestige. Another approach is building a strong alumni network of students by point out on benefits of having better alumni network. More events and activities for charities could be arranged and organized to improve the image of institutions.

\section{LIMITATION OF THE STUDY}

Several limitations arisen when doing this study, these limitations somewhat affected the research findings. The following issues are some of the limitations. Firstly, due to the time constraint, the questionnaires had to be distributed and collected within a short time period. Consequently, only 271 questionnaires were collected, which were not on par with the sample size of 392 . The researchers had to apply $6 \%$ sampling error instead of $5 \%$ as planned earlier. Therefore, the result of this study may not be generalized to represent the whole foreign students in Thailand. Secondly, the statements under all eight constructs may not cover all important satisfaction determinants. The statements may not be categorized clearly and may have similar descriptions. Thirdly, the researchers experienced multicollinearity problem in the multiple regression analysis because the independent variables were correlated with each other, and some had rather high degree of correlations. This problem may create unstable regression coefficients.

\section{FUTURE RESEARCH}

Because of the multicollinearity problem in this study, the researchers suggested future research to review and remove any independent variables that are highly correlated with others in a multiple regression equation. Another alternative is to combine correlated variables by using factor analysis to decrease number of variables.

To get more comprehensive study, further study can be conducted by taking a larger sample size. Increasing sample size could also reduce the impact of multicollinearity.

Regarding the adjusted $R^{2}(0.513=51.3 \%)$ from the study, it indicated that some factors explaining students satisfaction were still missing. Using focus group method or in-depth interview might help indicating other significant factors that were not captured in this study.

\section{REFERENCES}

[1] UNESCO Institute for Statistics. (2012). Global flow of tertiary-level students. [Online]. Available: http://www.uis.unesco.org/Education/Pages/international-student-flo w-viz.aspx

[2] World Education Services. (2013). Trends in international student mobility. [Online]. Available: http://www.wes.org/RAS

[3] Office of the Higher Education Commission, Bureau of International Cooperation Strategy, Ministry of Education. (2012). International programmes in higher education institutions. [Online]. Available: http://www.inter.mua.go.th/main2/article.php?id=301

[4] O. W. DeShield Jr., A. Kara, and E. Kaynak, "Determinants of business student satisfaction and retention in higher education: Applying Herzberg's two-factor theory," International Journal of Education Management, vol. 10, no. 2, pp. 128-139, 2005.

[5] Q. Wang, R. Taplin, and A. M. Brown, "Chinese students' satisfaction of the study abroad experience," International Journal of Education Management, vol. 25, no. 3, pp. 265-277, 2011. 
[6] R. Arambewela and J. Hall, "An empirical model of international student satisfaction," Asia Pacific Journal of Marketing and Logistics, vol. 21 , no. 4 , pp. 555-569, 2008

[7] A. Firdaus, "The development of HEdPERF: A new measuring instrument of service quality for higher education," International Journal of Consumer Studies, vol. 30, pp. 569-581, 2005.

[8] T. Gamage, J. Suwanabroma, T. Ueyama, S. Hada, and E. Sekikawa, "The impact of quality assurance measures on student services at the Japanese and Thai private universities," Quality Assurance in Education, vol. 16, no. 2, pp. 181-198, 2007.

[9] Q. Huang, "The relationship between service quality and student satisfaction in Higher education sector: A case study on the undergraduate sector of Xiamen University of China," AU Journal of Management, vol. 8, no.1, pp. 38-44, 2010.

[10] T. Techachaicherdchoo, "Undergraduate students' satisfaction toward the new education system in Thailand," International Journal of Social Sciences and Humanity Studies, vol. 3, no. 2, pp. 443-455, 2011.

[11] S. Li Phang "Factors influencing international students' study destination decision abroad," Master in Communication Thesis, University of Gothenburg, Department of Applied Information Technology, Gothenburg, Sweden, January 2013.

[12] Asaduzzaman, M. Hossain, and M. Rahman, "Service quality and student satisfaction: A case study on private universities in Bangladesh," International Journal of Economics, Finance and Management Sciences 2013, vol. 1, no. 3, pp. 128-135, 2013.

[13] Y. Mehdipour and H. Zerehkafi, "Student satisfaction at Osmania University," International Journal of Advancements in Research \& Technology, vol. 2, no. 6, pp. 233-240, 2013.
[14] D. George and P. Mallery, SPSS for Windows Step by Step: A Simple Guide and Reference. 11.0 Update, $4^{\text {th }}$ ed., Boston: Allyn \& Bacon, 2003

[15] Taro Yamane, Statistic: An Introductory Analysis, $2^{\text {nd }}$ ed., New York: Harper and Row, 1967

[16] Frederick M. Hess and Taryn Hochleitner. (May 2012). American Enterprise Institute. College rankings inflation: Are you overpaying for prestige? [Online]. Available: http://www.aei.org/outlook/educa tion/higher-education/consumer-information/college-rankings-inflatio $\mathrm{n}$-are-you-overpaying-for-prestige/

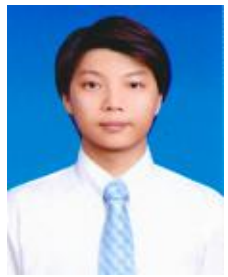

Teerapat Ngamkamollert received his bachelor's degree with first-class honors in Business Administration (International Business) from Rangsit International University. Currently, he is working in domestic textile business. Apart from working, he is enrolled in the master of management program of Chulalongkorn Business School, Chulalongkorn University.

Athapol Ruangkanjanases is a faculty member of Department of Commerce, Chulalongkorn Business School, Chulalongkorn University. He received his Ph.D. from Illinois Institute of Technology, USA. Before joining Chulalongkorn University, he was a full-time faculty member at the School of Management, Marist College, New York, USA. 